\title{
Genetic factors associated with rheumatoid arthritis and systemic vasculitis: Evaluation of a panel of polymorphisms
}

\author{
Elisa Menegatti ${ }^{\mathrm{a}, *}$, Annalisa Davit $^{\mathrm{a}}$, Simona Francica ${ }^{\mathrm{a}}$, Daniela Berardi ${ }^{\mathrm{a}}$, Daniela Rossi ${ }^{\mathrm{b}}$, \\ Simone Baldovino ${ }^{\mathrm{a}, \mathrm{c}}$, Pier Angelo Tovo ${ }^{\mathrm{d}}$, Luigi M. Sena ${ }^{\mathrm{a}}$ and Dario Roccatello ${ }^{\mathrm{a}, \mathrm{c}}$ \\ ${ }^{a}$ Department of Experimental Medicine and Oncology, Clinical Pathology Section, University of Turin, Turin, Italy \\ ${ }^{\mathrm{b}}$ Centro di Ricerche di Immunopatologia e Documentazione su Malattie Rare (CMID), Dipartimento di Malattie \\ Rare, Immunologiche, Ematologiche ed Immunoematologiche, ASL-TO2 NORD, Torino, Italy \\ ${ }^{\mathrm{c}}$ Centre of Research of Immunopathology and Rare Diseases, University of Turin, Turin, Italy \\ ${ }^{\mathrm{d}}$ Department of Pediatrics, University of Turin, Turin, Italy
}

\begin{abstract}
Immune and inflammatory response activation is a common feature of connective tissue diseases and systemic vasculitis. The aim of our study was to evaluate the possible involvement of TNF $\alpha$ c.-308A > G, IL-10 c.-1082A > G, uteroglobin c.38A > $\mathrm{G}, \mathrm{TGF} \beta 1 \mathrm{c} .869 \mathrm{C}>\mathrm{T}$ and $\mathrm{NF} \kappa \mathrm{B} 2$ c. $-1837 \mathrm{~T}>\mathrm{C}$ gene polymorphisms in susceptibility to connective tissue diseases. Our study cohort included 68 unrelated patients affected by rheumatoid arthritis (RA) (37 patients) and ANCA-positive [micropolyangiitis (mPA) 17 patients] or ANCA-negative systemic vasculitis [including 8 patients with Henoch-Schönlein purpura (HSP) and 6 patients with mixed cryoglobulinaemia (MC)] as well as 98 control subjects. Allele frequency analysis of uteroglobin c.38G $>$ A polymorphism showed a significant increase in the c.38A allele in patients $(p=0.002)$. Genotype frequency analysis of uteroglobin and NF- $\kappa \mathrm{B} 2$ gene polymorphisms in patients showed an increase in c.38GA and c.38AA genotypes in the uteroglobin gene $(p=0.02)$ coupled with an increase in homozygous c. $-1837 \mathrm{CC}$ in the NF- $\kappa \mathrm{B} 2$ gene $(p=0.02)$. Our data suggest that genetic variation in UG and NF- $\kappa \mathrm{B} 2$ pathways could have effects in connective tissue disease susceptibility.
\end{abstract}

Keywords: Connective diseases, systemic vasculitis, uteroglobin, polymorphisms

\section{Introduction}

Connective tissue diseases and systemic vasculitis are chronic multisystem disorders characterised by a wide spectrum of clinical presentations. Patients' clinical features can vary with regard to disease manifestations, age at onset, prognosis, and therapeutic response, likely depending upon interactions between susceptibility genes and various environmental factors. Changes in the delicate interplay between pro-

*Corresponding author: Elisa Menegatti PhD, Dipartimento di Medicina ed Oncologia Sperimentale, c.so Raffaello, 30, 10125, Torino, Italy. Tel.: +39 0 116707751; Fax: +39 0 116707753; E-mail: elisa.menegatti@unito.it. inflammatory and anti-inflammatory cytokines (i.e., TNF $\alpha$, IL-10, IL1-RA, uteroglobin (UG)) and sclerogenic factors (i.e., TGFß), coupled with activation of cell-mediated immune response seem to be characteristics that are shared by all connective tissue diseases. Genetic factors strongly affect the susceptibility, severity and therapeutic response in several autoimmune and inflammatory diseases. It has been shown that $\mathrm{TNF} \alpha$, TGFß, IL-10, IL1RN and uteroglobulin gene polymorphisms are associated with systemic lupus erythematosus (UG c. $38 \mathrm{G}>\mathrm{A}, \mathrm{TNF} \alpha$ c.-308A $>$ G) [1,2], rheumatoid arthritis (TGFß) [3], and juvenile idiopathic arthritis (TNF $\alpha$ c.-308A $>$ G) [4].

$\mathrm{TNF} \alpha$ is a potent proinflammatory cytokine involved in the pathogenesis of Rheumatoid Arthritis (RA) [5] 
and systemic lupus erythematosus (SLE) [6]. The minor allele at -308 base pairs from the transcription initiation site in the promoter of TNF $\alpha(\mathrm{TNF} \alpha-308 \mathrm{~A})$ has been associated with the production of TNF $\alpha$ and with susceptibility to SLE and juvenile idiopathic arthritis $[2,4]$.

Uteroglobin or Clara cell $10 \mathrm{kDa}$ protein $(\mathrm{CC} 10)$, the founding member of the Secretoglobin superfamily $(S c g b)$, is a multi-functional protein with potent anti-inflammatory and anti-chemotactic properties [7]. The minor allele (UG 38A) is significantly increased in SLE [1] and in asthma [8].

Interleukin-10 is a pleiotropic cytokine that possesses both immunosuppressive and immunostimulatory properties. Several studies have shown increased IL-10 production in SLE patients that correlates with disease activity. Increased IL-10 production may have a genetic basis, and polymorphism in the IL-10 promoter has been associated with SLE susceptibility [9].

Transforming growth factor $\beta 1$ (TGF $\beta 1$ ) is a key mediator of tissue fibrosis, and it regulates cell growth, apoptosis, and extracellular matrix synthesis as well. The TGF- $\beta 1+869 \mathrm{~T} / \mathrm{C}$ polymorphism, located in the region encoding the signal peptide, results in a leucine to proline substitution at amino acid position 10 . The $\mathrm{C}$ allele of this polymorphism shows a 2 to 8 -fold greater secretion of TGF- $\beta 1$ than the T allele in HeLa cells [10], and moreover, the $\mathrm{C}$ allele is associated with high serum concentrations of TGF- $\beta 1$ [11]. This difference in serum concentration is more apparent in the CC homozygote than in the CT and TT homozygotes. Associations have been reported between the TGF- $\beta 1+869 \mathrm{~T} / \mathrm{C}$ polymorphism and susceptibility to rheumatoid arthritis [3]. Interleukin (IL)-1 is a major pro-inflammatory cytokine which elicits a wide array of biologic activities that initiate and promote the host response to injury by activating a set of transcription factors, including $\mathrm{NF} \kappa \mathrm{B}$, which induce production of effectors of the inflammatory response. The IL-1 receptor antagonist (IL-1Ra) inhibits the activities of interleukin 1 alpha (IL1 $\alpha$ ) and interleukin 1 beta (IL1 $\beta$ ), and modulates a variety of IL- 1 related immune and inflammatory responses [12]. Five allelic polymorphisms (A1-A5) of an 86 base pair variable number tandem repeat (VNTR) in intron 2 have been described in the gene encoding IL-1Ra, known as IL-1RN [13]. Allele 2, which contains two copies of the VNTR, has been reported as being a risk and severity factor in SLE, ulcerative colitis, and Graves' disease [14-16].

Nuclear factor-B (NF-B)/Rel is a family of pleiotropic transcription factors that are activated by sever- al stimuli such as cytokines, UV radiation, oxidative stress, and bacterial or viral products. This family plays an important role in the regulation of the immune system in inflammatory response. Changes in NF- $\kappa \mathrm{B}$ activation can lead to the constitutive overproduction of pro-inflammatory cytokines, which is associated with a number of chronic inflammatory disorders including rheumatoid arthritis [17]. The NF- $\kappa \mathrm{B} 2$ gene is a member of the $(\mathrm{NF}-\kappa \mathrm{B}) / \mathrm{Rel}$ family that encodes for the $\mathrm{p} 100 / \mathrm{p} 52$ protein which is involved in the "nonclassical" NF-B pathway [17].

The aim of our study was to evaluate the possible involvement of TNF $\alpha$, TGFß, IL-10, IL1RN, uteroglobin (SCGB1A1, UG), and NF-kB2 gene polymorphisms in susceptibility to connective tissue diseases.

\section{Study population}

The study was performed on 68 unrelated patients of Italian Caucasian Ethnicity (38 females and 30 males; age range from 25 to 83 years) affected by rheumatoid arthritis (RA) (37 patients), ANCA-positive (systemic micropolyangiitis (PA) 17 patients) or ANCA-negative systemic vasculitis, including 8 patients with HenochSchönlein purpura (HSP) and 6 patients with mixed cryoglobulinaemia (MC). RA patients fulfilled the classification criteria of the American College of Rheumatology. Diagnosis of ANCA-associated micropoliangiitis was verified according to a recently proposed classification algoritm [18]. HSP was diagnosed according to Michel's criteria [19]. Diagnosis of MC followed criteria described elsewhere [20]. All vasculitis patients had biopsy-proven glomerulonephritis, with classical IgA dominant or codominant deposits in mesangium, diffuse mesangial hyperplasia and occasional fibrinoid necrosis in HSP cases, diffuse membrano-proliferative with pseudothrombi occluding capillary lumen in MC patients and pauciimmune focal necrotizing crescentic glomerulonephritis in MPA patients.

Polymorphism analysis was also performed on 98 control subjects (43 females and 55 males), recruited among the healthy blood donor population. Patients and controls provided informed consent to the study. The studies have been performed according to the Declaration of Helsinki, the procedures have been approved by the institutional review board (IRB). 
Table 1

a) PCR primers used for genotyping b) IL-1RN alleles

\begin{tabular}{|c|c|c|}
\hline Gene polymorphism & Forward primer & Reverse primer \\
\hline TNF $\alpha$ c. $-308 \mathrm{~A}>\mathrm{G}$ & 5'-aggcaataggttttgagggccatg-3' & 5'-tcctccetgetccgattccg-3' \\
\hline IL- 10 c. $-1082 A>G$ & 5 '-gtcagtgttcctcccagt-3, & $5^{\prime}-$ ttacctatccetacttcctc- $3^{\prime}$ \\
\hline UG c. $38 \mathrm{G}>\mathrm{A}$ & $5^{\prime}$-cagtatcttatgtagagccc- 3 , & $5^{\prime}$-cctggagacatgtgccttct- 3 , \\
\hline TGF $\beta$ g.869T $>C$ & 5 '-ctaccttttgccgggagacc- 3 , & 5'-ggcgcgccgcagcttggaca-3' \\
\hline $\mathrm{NF}-\kappa \mathrm{B} 2 \mathrm{c} .1837 \mathrm{~T}>\mathrm{C}$ & $5^{\prime}$-gagccetgctggcaggcgacg-3, & 5 -agagggaggagggcctttag-3, \\
\hline IL1RN 86 bp VNTR & $5^{\prime}$-ctcagcaacactcctat-3' & 5'-tcctggtctgcaggtaa-3' \\
\hline \multicolumn{3}{|l|}{ b) } \\
\hline \multicolumn{2}{|c|}{ IL1RN 86 bp VNTR alleles } & PRODUCT SIZE (bp) \\
\hline \multicolumn{2}{|c|}{ A1 = 86bp VNTR 2 copies } & 240 \\
\hline \multicolumn{2}{|c|}{$\mathrm{A} 2=86 \mathrm{bp}$ VNTR 3 copies } & 326 \\
\hline \multicolumn{2}{|c|}{$\mathrm{A} 3=86 \mathrm{bp}$ VNTR 4 copies } & 412 \\
\hline \multicolumn{2}{|c|}{$\mathrm{A} 4=86 \mathrm{bp}$ VNTR 5 copies } & 498 \\
\hline
\end{tabular}

\section{Laboratory analyses}

Genomic DNA was purified from $300 \mu$ l of whole blood using the Wizard Genomic DNA Purification Kit (Promega, Madison, Wisconsin) according to the manufacturer's instructions.

TNF $\alpha-308 \mathrm{~A}>$ G, IL-10 c. $-1082 \mathrm{~A}>\mathrm{G}$, uteroglobin c.38A $>$ G, TGF $\beta 1$ c.869C $>$ T and NF- $\kappa$ B2 c.$1837 \mathrm{~T}>\mathrm{C}$ polymorphisms were genotyped by Restriction Fragment Length Polymorphism analysis (PCRRFLP). DNA samples were amplified by polymerase chain reaction (PCR) followed by enzymatic digestion. The PCR reactions were performed in total volume of $25 \mu \mathrm{l}$ containing $10 \mathrm{ng}$ of genomic DNA, 1X PCR buffer, 0.625 units of Taq DNA polymerase (Applied Biosystems, Monza, Italy), $1.5 \mathrm{mM} \mathrm{MgCl}_{2}, 0.25 \mathrm{mM}$ dNTPs, and 6 pmol of each primer. Thermal cycling conditions were as follows: denaturation step at $95^{\circ} \mathrm{C}$ for $3 \mathrm{~min}, 35$ cycles at $94^{\circ} \mathrm{C}$ for $30 \mathrm{sec}, 30 \mathrm{sec}$ at $57^{\circ} \mathrm{C}$ for TNF $\alpha$, IL1RN, IL-10 and Uteroglobin, at $59^{\circ} \mathrm{C}$ for TGF $\beta 1$ and NF- $\kappa \mathrm{B} 2$, and a final extension step at $72{ }^{\circ} \mathrm{C}$ for $5 \mathrm{~min}$. The primers we used are listed in Table 1.

The $-308 \mathrm{~A}>\mathrm{G}$ polymorphism, which is located in the promoter region of the TNF $\alpha$ gene, was identified by digestion of the $107 \mathrm{bp}$ PCR product by the NcoI enzyme: the $G$ allele was cut into $82 \mathrm{bp}$ and $25 \mathrm{bp}$ fragments, the A allele was not digested. Digestion products were electrophoresed on an $8 \%$ polyacrylamide gel and visualised with ethidium bromide staining. IL$10-1082 \mathrm{~A}>\mathrm{G}$, a transition at position -1082 in the promoter region, was identified by EamI digeston of the $282 \mathrm{bp}$ PCR product, the A allele was cut into 273 bp and 19 bp fragments, the $G$ allele was not digested.

Uteroglobin $\mathrm{A} \rightarrow \mathrm{G}$ transition, at position 38 in exon 1 was analysed by Sau96I digestion of the 258 bp PCR product, the $\mathrm{G}$ allele was cut into $130 \mathrm{bp}$ and $128 \mathrm{bp}$ fragments, the A allele was not digested.
The Leu ${ }^{10} \rightarrow$ Pro polymorphism, a transition $\mathrm{T} \rightarrow \mathrm{C}$ at nucleotide 29 in exon 1 of the TGF $\beta 1$ gene was analysed by digesting the $110 \mathrm{bp}$ PCR product with PstI, the T allele was cut into $86 \mathrm{bp}$ and $24 \mathrm{bp}$ fragments, the $\mathrm{C}$ allele was not digested.

The $\mathrm{T} \rightarrow \mathrm{C}$ transition in the NF- $\kappa \mathrm{B} 2$ gene was analysed by MaeII digestion of the $149 \mathrm{bp}$ PCR product, the $\mathrm{T}$ allele was cut into $127 \mathrm{bp}$ and $22 \mathrm{bp}$ fragments, the $\mathrm{C}$ allele was not digested. These products were electrophoresed on $2.5 \%$ or $3 \%$ agarose gel and visualised with ethidium bromide staining.

In order to analyse the IL-1RN gene 86 bp repeated sequence (VNTR), located in intron 2, DNA was amplified by PCR (Table 1) and PCR product size was analysed by electrophoresis on a $4 \%$ NuSieve-agarose (3:1) gel.

\section{Statistical analysis}

Allele and genotype frequencies were calculated by the gene counting method, and the Hardy-Weinberg equilibrium was tested. Differences in allele and genotype frequencies in patients and controls were calculated by the Chi-square test and Fisher's exact test. We calculated genotype odds ratios (OR) with confidence intervals (CI) of $95 \%$ for each individual polymorphism.

Statistical analysis was performed with SNPAlyze v7.0 (Dynacom Co, Ltd, Japan). P-values $<0.05$ were considered statistically significant.

\section{Results}

Sixty-eight patients with connective tissue diseases and 98 controls were genotyped for $\mathrm{TNF} \alpha-308 \mathrm{~A}>$ 
Table 2

Distribution of genotypes and alleles in patients with connective tissue disease and in controls

\begin{tabular}{|c|c|c|c|c|c|c|c|c|}
\hline & Alleles & Patients N (\%) & Controls N (\%) & $\mathrm{P}^{*}$ & Genotype & Patients N (\%) & Controls N (\%) & $\mathrm{P}^{\circ}$ \\
\hline \multirow{3}{*}{$\mathrm{TNF} \alpha$} & $G$ & $93(84.54)$ & $162(85.26)$ & \multirow{6}{*}{0.59} & GG & $41(74.50)$ & $71(74.75)$ & \multirow{3}{*}{0.93} \\
\hline & A & $17(15.46)$ & $28(14.74)$ & & GA & $11(20)$ & $20(21.05)$ & \\
\hline & & & & & AA & $3(5.50)$ & $4(4.2)$ & \\
\hline \multirow{3}{*}{ IL-10 } & $\mathrm{G}$ & $87(76.31)$ & $156(79.59)$ & & GG & $39(68.42)$ & $72(73.47)$ & \multirow{3}{*}{0.77} \\
\hline & A & $27(23.69)$ & $40(20.41)$ & & GA & $9(15.79)$ & $12(12.24)$ & \\
\hline & & & & & AA & $9(15.79)$ & $14(14.29)$ & \\
\hline \multirow{3}{*}{ UG (SCGB1) } & G & $66(55)$ & $157(69)$ & \multirow{3}{*}{0.002} & GG & $19(31.70)$ & $58(51)$ & \multirow{3}{*}{0.04} \\
\hline & A & $54(45)$ & $71(31)$ & & GA & $28(46.60)$ & $41(36)$ & \\
\hline & & & & & AA & $13(21.70)$ & $15(13)$ & \\
\hline \multirow{3}{*}{$\mathrm{TGF} \beta$} & $\mathrm{C}$ & $80(58.82)$ & $95(48.47)$ & \multirow{3}{*}{0.08} & $\mathrm{CC}$ & $25(36.76)$ & $24(24.5)$ & \multirow{3}{*}{0.19} \\
\hline & $\mathrm{T}$ & $56(41.18)$ & $101(51.53)$ & & $\mathrm{CT}$ & $30(44.12)$ & $47(47.96)$ & \\
\hline & & & & & TT & $13(19.12)$ & $27(27.55)$ & \\
\hline \multirow{3}{*}{ NFkB2 } & $\mathrm{T}$ & $112(87.50)$ & $150(88.23)$ & \multirow{3}{*}{0.98} & TT & $53(82.80)$ & $66(77.65)$ & \multirow{3}{*}{0.02} \\
\hline & $\mathrm{C}$ & $16(12.50)$ & $20(11.77)$ & & $\mathrm{TC}$ & $6(9.40)$ & $18(21.18)$ & \\
\hline & & & & & $\mathrm{CC}$ & $5(7.80)$ & $1(1.18)$ & \\
\hline \multirow{5}{*}{ IL1RN } & A1 & $24(18.46)$ & $25(12.88)$ & & A1A1 & $9(13.85)$ & $7(7.22)$ & \multirow{5}{*}{0.56} \\
\hline & A3 & $100(76.92)$ & $164(84.53)$ & & A1A3 & $6(9.23)$ & $11(11.34)$ & \\
\hline & A4 & $6(4.62)$ & $5(2.58)$ & 0.21 & A3A3 & $46(70.77)$ & 75 (77.32) & \\
\hline & & & & & A3A4 & $2(3.08)$ & 3 & \\
\hline & & & & & A4A4 & $2(3.08)$ & 1 & \\
\hline
\end{tabular}

$\left(^{*}\right) \mathrm{p}$ values from $2 \times 2$ contingency table: patients vs controls.

$\left({ }^{\circ}\right)$ p values from $3 \times 2$ contingency table: patients vs controls.

Table 3

\begin{tabular}{lcc}
\multicolumn{3}{c}{ Odds ratio evaluation for UG alleles } \\
\hline UG $^{*}$ & P value & OR $(95 \% \mathrm{CI})$ \\
\hline GA & 0.07 & $1.83(0.94-3.56)$ \\
AA & 0.06 & $2.64(1.07-6.54)$ \\
GA/AA & 0.03 & $1.9(1.04-3.6)$ \\
\hline * compared to GG.
\end{tabular}

G, IL-10 -1082A > G, uteroglobin 38A > G, TGF $\beta 1$ c. $869 \mathrm{C}>\mathrm{T}, \mathrm{NF}-\kappa \mathrm{B} 21837 \mathrm{~T}>\mathrm{C}$ and IL-1RN 86bp VNTR. Table 3 shows genotype and allele distribution for the polymorphisms that were studied. The genotype and the allele frequencies we observed were not significantly different from what was expected according to the Hardy-Weinberg Equilibrium in the control group.

Allele frequency analysis of uteroglobin $38 \mathrm{G}>\mathrm{A}$ polymorphism showed a significant increase in the $38 \mathrm{~A}$ allele in patients as compared to controls $(p=0.02)$. TNF $\alpha$ IL-10, TGF $\beta$, NF- $\kappa$ B2 IL-1RN allele frequency distribution was not significantly different in patients compared to controls.

Genotype frequency analysis of the uteroglobin gene showed an increase in GA and AA genotypes in patients as compared to controls $(p=0.04)$. With regards to the $\mathrm{NF}-\kappa \mathrm{B} 2$ gene, we observed a statistically significant decrease in heterozygous individuals (TC) and an increase in homozygous ones $(p=0.02)$. No significant differences were found with regards to TNF $\alpha$ IL-10, $\operatorname{TGF} \beta$, and IL-1RN genotype frequency distribution between patients and controls (Table 2).
Odds ratio calculation showed that individuals bearing AA and GA genotypes in the uteroglobin gene have a greater risk of developing a connective tissue disease $(\mathrm{OR}=2.64,95 \% \mathrm{CI}=1.07-6.54 \mathrm{AA}$ vs $\mathrm{GG}$, and $\mathrm{OR}=2.0895 \% \mathrm{CI}=1.03-4.23 \mathrm{GA}$ vs GG, respectively), compared to homozygous GG with an overall Odds Ratio of $2.23(95 \% \mathrm{CI}=1.16-4.31)$ calculated on GG vs GA + AA. On the contrary, NF- $\kappa$ B2 CT and $\mathrm{CC}$ genotypes seem to play a protective role (TT vs $\mathrm{CT}+\mathrm{CC} \mathrm{OR}=0.7295 \% \mathrm{CI}=0.31-1.64)$ and individuals with UG c.38GG and NF- $\kappa \mathrm{B} 2$ c. $1837 \mathrm{CC}$ or TC genotype had a significantly lower risk of developing a connective tissue disease $(\mathrm{OR}=0.33,95 \% \mathrm{CI}=$ $0.08-1.23)$.

We performed separate statistical analyses for the RA group and for the group of vasculitis affected patients (PA). Polymorphism analysis in RA patients (37) showed a significant increase in the uteroglobin 38A allele $(p=0.02)$, and in the uteroglobin 38GA and 38AA genotypes in patients as compared to controls $(p=0.02)$. The risk of RA was more than two times higher in patients bearing the uteroglobin 38A allele in either the homozygous (AA) or in the heterozygous state $(\mathrm{GA})(\mathrm{OR}=2.6495 \% \mathrm{CI}=1.1-6.2)$.

Polymorphism analysis in vasculitis patients showed an increase in the uteroglobin 38A allele $(p=0.06$ $\mathrm{OR}=1.8$ 95\% CI 0.96-3.24). $\mathrm{TNF} \alpha \mathrm{IL}-10, \mathrm{TGF} \beta$, NF- $\kappa$ B 2 and IL-1RN allele and genotype frequency distribution was not significantly different in patients as compared to controls (Table 4). 
Table 4

Distribution of genotypes and alleles in patients with RA and vasculitis (PA, CRIO, SH) and in controls

\begin{tabular}{|c|c|c|c|c|c|c|c|c|c|c|c|c|}
\hline & Allele & $\begin{array}{c}\text { Controls } \\
\mathrm{N}(\%)\end{array}$ & $\begin{array}{c}\text { RA } \\
\mathrm{N}(\%)\end{array}$ & $\mathrm{P}^{*}$ & $\begin{array}{c}\text { PA,SH,CRIO } \\
\text { N (\%) }\end{array}$ & $\mathrm{P}^{*}$ & Genotype & $\begin{array}{c}\text { Controls } \\
\mathrm{N}(\%)\end{array}$ & $\begin{array}{c}\mathrm{RA} \\
\mathrm{N}(\%)\end{array}$ & $\mathrm{P}^{\circ}$ & $\begin{array}{c}\mathrm{PA}, \mathrm{SH}, \mathrm{CRIO} \\
\mathrm{N}(\%)\end{array}$ & $\mathrm{P}^{\circ}$ \\
\hline & $G$ & $162(85.3)$ & $56(87.5)$ & & $46(85.2)$ & & GG & $71(74.8)$ & $26(81.25)$ & & $19(70.37)$ & \\
\hline \multirow[t]{3}{*}{$\mathrm{TNF} \alpha$} & A & $28(14.7)$ & $8(12.5)$ & 0.65 & $8(14.8)$ & 0.98 & GA & $20(21)$ & $4(12.5)$ & 0.53 & $8(29.62)$ & 0.39 \\
\hline & & & & & & & $\mathrm{AA}$ & $4(4.2)$ & $2(6.25)$ & & $0(-)$ & \\
\hline & $\mathrm{G}$ & $156(79.6)$ & 49 (79) & & $36(72)$ & & GG & $72(73.5)$ & $24(77.4)$ & & $14(56)$ & \\
\hline \multirow[t]{2}{*}{ IL-10 } & A & $40(20.46)$ & $13(21)$ & 0.93 & $14(28)$ & 0.33 & GA & $12(12.2)$ & $1(3.2)$ & 0.31 & $8(32)$ & 0.06 \\
\hline & & & & & & & AA & $14(14.3)$ & $6(19.4)$ & & $3(12)$ & \\
\hline UG & $\mathrm{G}$ & 157 (69) & $34(53.1)$ & & $30(55.6)$ & & GG & $58(51)$ & $9(28.1)$ & & $10(37)$ & \\
\hline \multirow[t]{3}{*}{ (SCGB1) } & A & $71(31)$ & $30(46.9)$ & 0.02 & $24(44.4)$ & 0.08 & GA & $41(36)$ & $16(50)$ & 0.06 & $10(37)$ & 0.21 \\
\hline & & & & & & & AA & $15(13)$ & $7(21.9)$ & & $7(26)$ & \\
\hline & $\mathrm{C}$ & $95(48.5)$ & $43(58.1)$ & & $23(57.5)$ & & $\mathrm{CC}$ & $24(24.5)$ & $14(37.8)$ & & $6(30)$ & \\
\hline \multirow[t]{3}{*}{$\mathrm{TGF} \beta$} & $\mathrm{T}$ & $101(51.5)$ & 31 (41.9) & 0.20 & $17(42.5)$ & 0.39 & $\mathrm{CT}$ & 47 (48) & $15(40.5)$ & 0.30 & $11(55)$ & 0.50 \\
\hline & & & & & & & $\mathrm{TT}$ & $27(27.55)$ & $8(21.6)$ & & $3(15)$ & \\
\hline & $\mathrm{T}$ & $150(88.2)$ & $62(88.6)$ & & $49(87.5)$ & & $\mathrm{TT}$ & $66(77.66)$ & $29(82.8)$ & & $23(82.1)$ & \\
\hline \multirow[t]{3}{*}{ NFkB2 } & $\mathrm{C}$ & $20(11.8)$ & 8 (11.4) & 0.21 & $7(12.5)$ & 0.15 & $\mathrm{TC}$ & $18(21.2)$ & 4 (11.4) & 0.18 & $3(10.7)$ & 0.13 \\
\hline & & & & & & & $\mathrm{CC}$ & $1(1.2)$ & $2(5.7)$ & & $2(7.2)$ & \\
\hline & A1 & $25(12.9)$ & 13 (18.6) & & $6(11.5)$ & & $\mathrm{A} 1 \mathrm{~A} 1$ & $7(7.22)$ & $6(17.1)$ & & $2(7.7)$ & \\
\hline \multirow[t]{4}{*}{ IL1RN } & A3 & $164(84.5)$ & $54(77.1)$ & & $43(82.7)$ & & $\mathrm{A} 1 \mathrm{~A} 3$ & $11(11.34)$ & $1(2.9)$ & & $2(7.7)$ & \\
\hline & A4 & $5(2.6)$ & $3(4.3)$ & 0.37 & $3(5.8)$ & 0.51 & A3A3 & 75 (77.32) & $26(74.3)$ & 0.27 & $20(76.9)$ & 0.86 \\
\hline & & & & & & & $\mathrm{A} 3 \mathrm{~A} 4$ & $3(3.09)$ & $1(2.9)$ & & $1(3.8)$ & \\
\hline & & & & & & & A4A4 & $1(1.03)$ & $1(2.9)$ & & $1(3.8)$ & \\
\hline
\end{tabular}

$\left({ }^{*}\right)$ p values from $2 \times 2$ contingency table: patients vs controls.

$\left({ }^{\circ}\right)$ p values from $3 \times 2$ contingency table: patients vs controls.

\section{Discussion}

Activation of immune and inflammatory response is a common feature of rheumatoid arthritis and systemic vasculitis. It has been shown that cytokine polymorphisms may affect gene transcription, thus causing individual variations in cytokine production that could lead to predisposition to autoimmune and inflammatory disorders $[1,2,9,14]$. We studied the possible association between gene polymorphisms of the key factors of inflammation and fibrosis (TNF- $\alpha$, TGFß, IL10 , IL1-RN, uteroglobin and NF- $\kappa \mathrm{B} 2$ ) and susceptibility towards developing connective tissue diseases. We showed that uteroglobin c. $38 \mathrm{G}>\mathrm{A}$ and NF- $\kappa \mathrm{B} 2$ c. $1837 \mathrm{~T}>\mathrm{C}$ and polymorphisms were associated to both vasculitis and connective tissue diseases.

Uteroglobin is a multifunctional protein with anti inflammatory/immunomodulatory properties that interferes with IFN $\gamma$ and TNF $\alpha$-mediated actions and diminishes their biological activity $[21,22]$. The c.38G $>$ A polymorphism in the uteroglobin gene, which is located downstream from the transcription initiation site, within the noncoding region of exon 1 , is correlated with an increased risk of developing immune-mediated diseases such as Systemic Lupus Erythematosus [1], asthma [8] and rheumatoid arthritis [23]. The c.38G > A polymorphism is located within a region corresponding to the rat minimal promoter which was shown to play a key role in transcriptional regulation. Evidence suggests that change in the UG exon 1 noncoding region might affect the physiologic counteracting mechanisms of inflammation and UG protein expression. In fact, a significant reduction in plasma UG levels has been observed in 38AA individuals [8].

Separate analysis of the distribution of polymorphisms was performed for RA and systemic vasculitis patients. Results showed an increase in UG 38A allele frequency in both groups. Previous studies on the possible role of the A38G polymorphism in immune-mediated diseases have yielded conflicting results [23,24], likely due to differences in the genetic background of patient samples study design. The uteroglobin gene is located in a $170 \mathrm{~kb}$ region on chromosome $11 \mathrm{p} 12.3$ where other members of the secretoglobin gene family have been mapped. The close proximity of 5 secretoglobin gene family members suggests that uteroglobin $38 \mathrm{~A}$ or $\mathrm{G}$ allele could be in linkage with polymorphisms located in one secretoglobin family member, thus explaining some of the discrepancies in results. Besides, selection of population may be important. For instance, prevalence of the $38 \mathrm{G}$ allele is only slightly increased in HSP children without nephritis [24], while clearly significant in patient progressing towards renal failure [1]. With regard to the relevance of our findings in RA patients, it should be mentioned that clinical disease activity in patients with early RA can be frequently controlled by conventional therapy and especially by the new antirheumatic agents. Even 
with the use of DMARDS and advanced therapeutics in RA, erosion may occur. Polymorphism in the UG gene has been regarded as a promising novel marker of radiographic progression [23]. A prospective study relating progressive erosive disease and UG gene polymorphism is currently ongoing in our department.

The NF- $\kappa \mathrm{B}$ family of transcription factors (composed of NF- $\kappa$ B1 (p105/p50), NF- $\kappa$ B2 (p100/p52), cRel, RelA, and RelB) regulates the expression of a wide range of immune response genes whose products play a critical role in orchestrating inflammatory responses. Inappropriate activation of NF- $\kappa$-B has been linked to inflammatory events associated with autoimmune arthritis [25]. The NF- $\kappa \mathrm{B} 2$ gene encodes for the p100 protein precursor that is cleaved in the active p52 in response to several stimuli such as lymphotoxin $\beta$, CD40L and the B-cell activating factor that is involved in autoimmune diseases [26].

$\mathrm{NF}-\kappa \mathrm{B} 2$ is highly regulated both at transcriptional and post-transcriptional level. At present, no data are available on the association between the NF- $\kappa \mathrm{B} 2$ polymorphism and immuno-mediated diseases but the NF$\kappa \mathrm{B}$ pathway is currently thought to be the major intracellular pathway in RA pathogenesis. The NF- $\kappa \mathrm{B} 2$ c. $1837 \mathrm{~T}>\mathrm{C}$ variant is located in the promoter region close to $\kappa \mathrm{B}$ sites, being putatively involved in promoter regulation [26]. Our data showed that uteroglobin A allele in either the homozygous or in the heterozygous state seems increased in connective tissue disease $(\mathrm{OR}=2.23,95 \% \mathrm{CI}=1.16-4.3, p=0.02)$. Some effect of the variation in the NF- $\kappa \mathrm{B} 2$ gene in connective tissue disease susceptibility have been observed as well.

The possible role of uteroglobin and NF- $\kappa \mathrm{B} 2$ the pathogenesis of RA and systemic vasculitis requires further clarification, and a greater number of studies involving larger cohorts of patients are needed. Albeit our data are limited both in size samples and ethnicity, a "general" genetic predisposition towards developing tissue disease regardless of the pathogenetic mechanisms involved in the various disorders could be envisaged. This could be due to changes in the mediators involved in the cellular activation pathways that are shared by all immuno-mediated disorders.

\section{References}

[1] E. Menegatti, A. Nardacchione, M. Alpa, C. Agnes, D. Rossi, M. Chiara, V. Modena, L.M. Sena and D. Roccatello, Polymorphism of the uteroglobin gene in systemic lupus erythematosus and IgA nephropathy, Lab Invest 82 (2002), 543-546.
[2] Y.H. Lee, J.B. Harley and S.K. Nath, Meta-analysis of TNFalpha promoter -308 A/G polymorphism and SLE susceptibility, Eur J Hum Genet 14 (2006), 364-371.

[3] D.L. Mattey, N. Nixon, P.T. Dawes and J. Kerr, Association of polymorphism in the transforming growth factor $\{$ beta $\} 1$ gene with disease outcome and mortality in rheumatoid arthritis, Ann Rheum Dis 64 (2005), 1190-1194.

[4] H. Schmeling, U. Wagner, A. Peterson and G. Horneff, Tumor necrosis factor alpha promoter polymorphisms in patients with juvenile idiopathic arthritis, Clin Exp Rheumatol 24 (2006), 103-108.

[5] G. Schett, Review: Immune cells and mediators of inflammatory arthritis, Autoimmunity 41 (2008), 224-229.

[6] M. Aringer, E. Feierl, G. Steiner, G.H. Stummvoll, E. Höfler, C.W. Steiner, I. Radda, J.S. Smole and W.B. Graninger, Increased bioactive TNF in human systemic lupus erythematosus: associations with cell death, Lupus 11 (2002), 102-108.

[7] A.B. Mukherjee, Z. Zhang and B.S. Chilton, Uteroglobin: a steroid-inducible immunomodulatory protein that founded the Secretoglobin superfamily, Endocr Rev 28 (2007), 707-725.

[8] I.A. Laing, C. Hermans, A. Bernard, P.R. Burton, J. Goldblatt and P.N. Le Souëf, Association between plasma CC16 levels, the A38G polymorphism, and asthma, Am J Respir Crit Care Med 161 (2000), 124-127.

[9] A.W. Gibson, J.C. Edberg, J. Wu, R.G. Westendorp, T.W. Huizinga and R.P. Kimberly, Novel single nucleotide polymorphisms in the distal IL-10 promoter affect IL-10 production and enhance the risk of systemic lupus erythematosus, $J$ Immunol 166 (2001), 3915-3922.

[10] A.M. Dunning, P.D. Ellis, S. McBride, H.L. Kirschenlohr, C.S. Healey, P.R. Kemp, R.N. Luben, J. Chang-Claude, A. Mannermaa, V. Kataja, P.D. Pharoah, D.F. Easton, B.A. Ponder and J.C. Metcalfe, A transforming growth factor betal signal peptide variant increases secretion in vitro and is associated with increased incidence of invasive breast cancer, Cancer Res 63 (2003), 2610-2615.

[11] M. Yokota, S. Ichihara, T.L. Lin, N. Nakashima and Y. Yamada, Association of a T29 $\rightarrow$ C polymorphism of the transforming growth factor-beta1 gene with genetic susceptibility to myocardial infarction in Japanese, Circulation 101 (2000), 2783-2787.

[12] W.P. Arend, M. Malyak, C.J. Guthridge and C. Gabay, Interleukin-1 receptor antagonist: role in biology, Annu Rev Immunol 16 (1998), 27-55.

[13] J.K. Tarlow, A.I. Blakemore, A. Lennard, R. Solari, H.N. Hughes, A. Steinkasserer and G.W. Duff, Polymorphism in human IL-1 receptor antagonist gene intron 2 is caused by variable numbers of an 86-bp tandem repeat, Hum Genet 91 (1993), 403-404.

[14] A.I. Blakemore, J.K. Tarlow, M.J. Cork, C. Gordon, P. Emery and G.W. Duff, Interleukin-1 receptor antagonist gene polymorphism as a disease severity factor in systemic lupus erythematosus, Arthritis Rheum 37 (1994), 1380-1385.

[15] G. Bioque, J.B. Crusius, I. Koutroubakis, G. Bouma, P.J. Kostense, S.G. Meuwissen and A.S. Peña, Allelic polymorphism in IL-1 beta and IL-1 receptor antagonist (IL-1Ra) genes in inflammatory bowel disease, Clin Exp Immunol 102 (1995), 379-383.

[16] A.I. Blakemore, P.F. Watson, A.P. Weetman and G.W. Duff, Association of Graves' disease with an allele of the interleukin1 receptor antagonist gene, J Clin Endocrinol Metab 80 (1995), 111-115.

[17] S. Beinke and S.C. Ley, Functions of NF- $\kappa \mathrm{B} 1$ and NF- $\kappa \mathrm{B} 2$ in immune cell biology, Biochem J 382 (2004), 393-409. 
[18] G. Cees and M. Kallemberg, The last classification of vasculitis, Clinic Rev Allerg Immunol 35 (2008), 5-10.

[19] B.A. Michel, G.G. Hunder, D.A. Bloch and L.H. Calabrese, Hypersensitivity vasculitis and Henoch-Schönlein purpura: a comparison between the 2 disorders, J Rheumatol 19 (1992), 721-728.

[20] D. Roccatello, A. Fornasieri, O. Giachino, D. Rossi, A. Beltrame, G. Banfi, R. Confalonieri, A. Tarantino, S. Pasquali, A. Amoroso, S. Savoldi, V. Colombo, C. Manno, A. Ponzetto, L. Moriconi, A. Pani, R. Rustichelli, G.B. Di Belgiojoso, C. Comotti and M.I. Quarenghi, Multicenter study on hepatitis $\mathrm{C}$ virus-related cryoglobulinemic glomerulonephritis, $\mathrm{Am}$ J Kidney Dis 49 (2007), 69-82.

[21] I. Dierynck, A. Bernard, H. Roels and M. De Ley, Potent inhibition of both human interferon-gamma production and biologic activity by the Clara cell protein CC16, Am J Respir Cell Mol Biol 12 (1995), 205-210.

[22] X.L. Yao, S.J. Levine, M.J. Cowan, C. Logun and J.H. Shel- hamer, Tumor necrosis factor-alpha stimulates human Clara cell secretory protein production by human airway epithelial cells, Am J Respir Cell Mol Biol 19 (1998), 629-635.

[23] J.J. Goronzy, E.L. Matteson, J.W. Fulbright, K.J. Warrington, A. Chang-Miller, G.G. Hunder, T.G. Mason, A.M. Nelson, R.M. Valente, C.S. Crowson, H.A. Erlich, R.L. Reynolds, R.G. Swee, W.M. O'Fallon and C.M. Weyand, Prognostic markers of radiographic progression in early rheumatoid arthritis, Arthritis Rheum 50 (2004), 43-54.

[24] E.M. Eisenstein and M. Choi, Analysis of a uteroglobin gene polymorphism in childhood Henoch-Schonlein purpura, Pediatr Nephrol 21 (2006), 782-784.

[25] S. Bacher and M.L. Schmitz, The NF- $\kappa$ B pathway as a potent target for autoimmune disease theraphy, Curr Pharm Design 10 (2004), 2827-2837.

[26] E. Dejardin, The alternative NF- $\kappa$ B pathway from biochemistry to biology: pitfalls and promises for future drug development, Biochem Pharmacol 72 (2006), 1161-1179. 


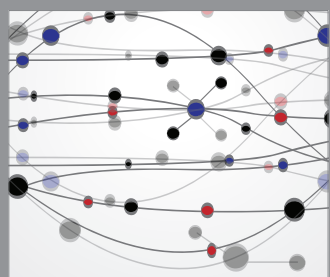

The Scientific World Journal
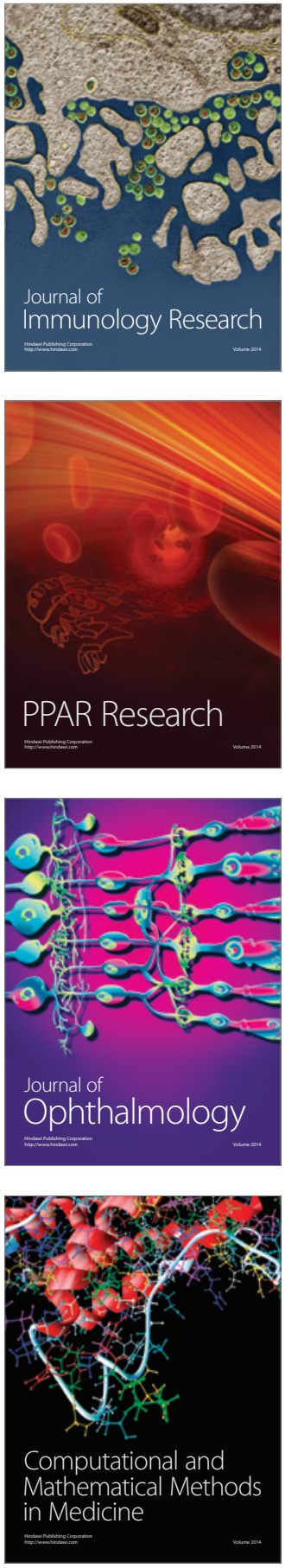

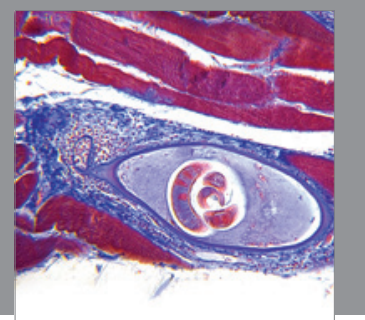

Gastroenterology

Research and Practice
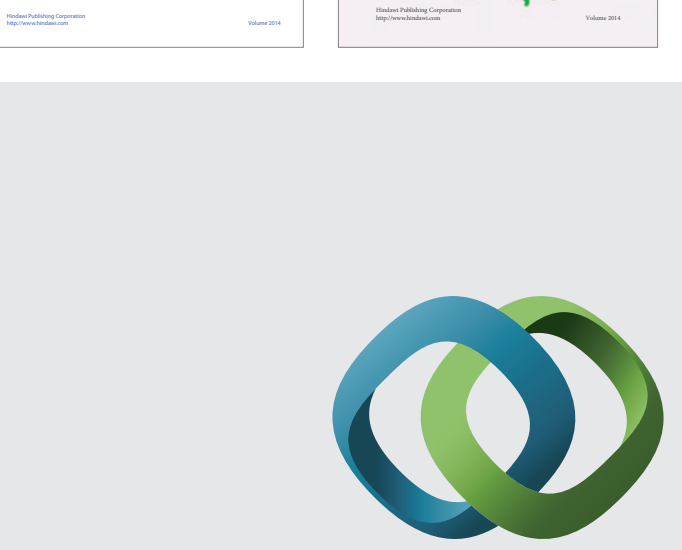

\section{Hindawi}

Submit your manuscripts at

http://www.hindawi.com
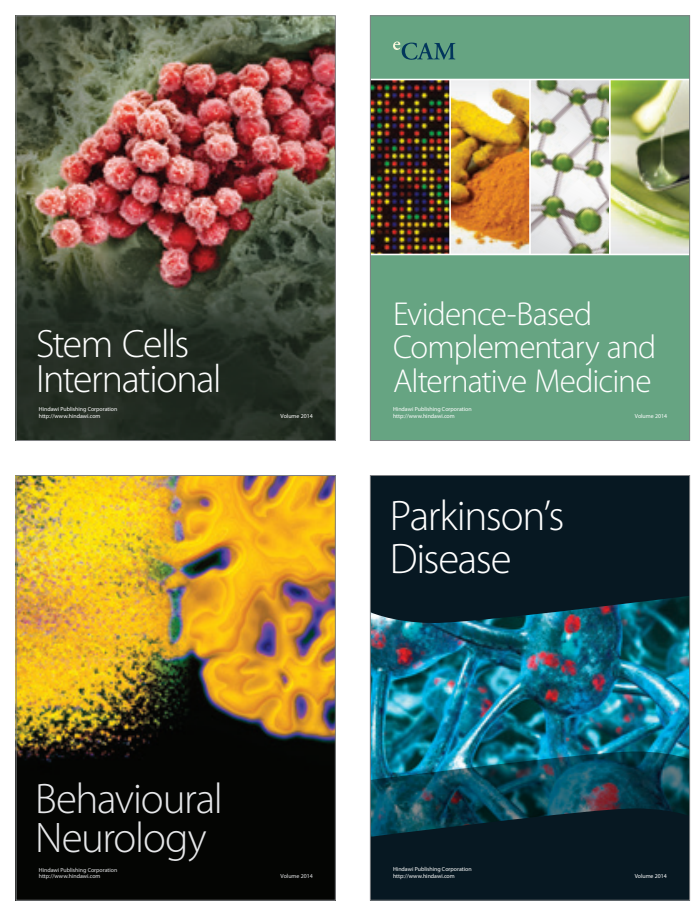

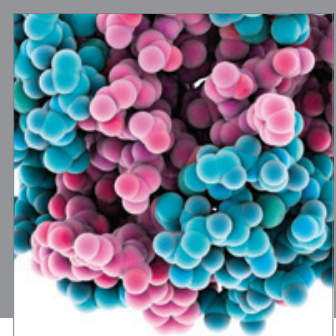

Journal of
Diabetes Research

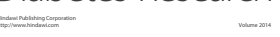

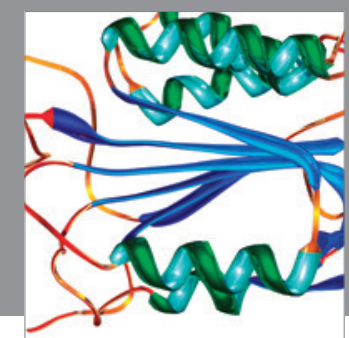

Disease Markers
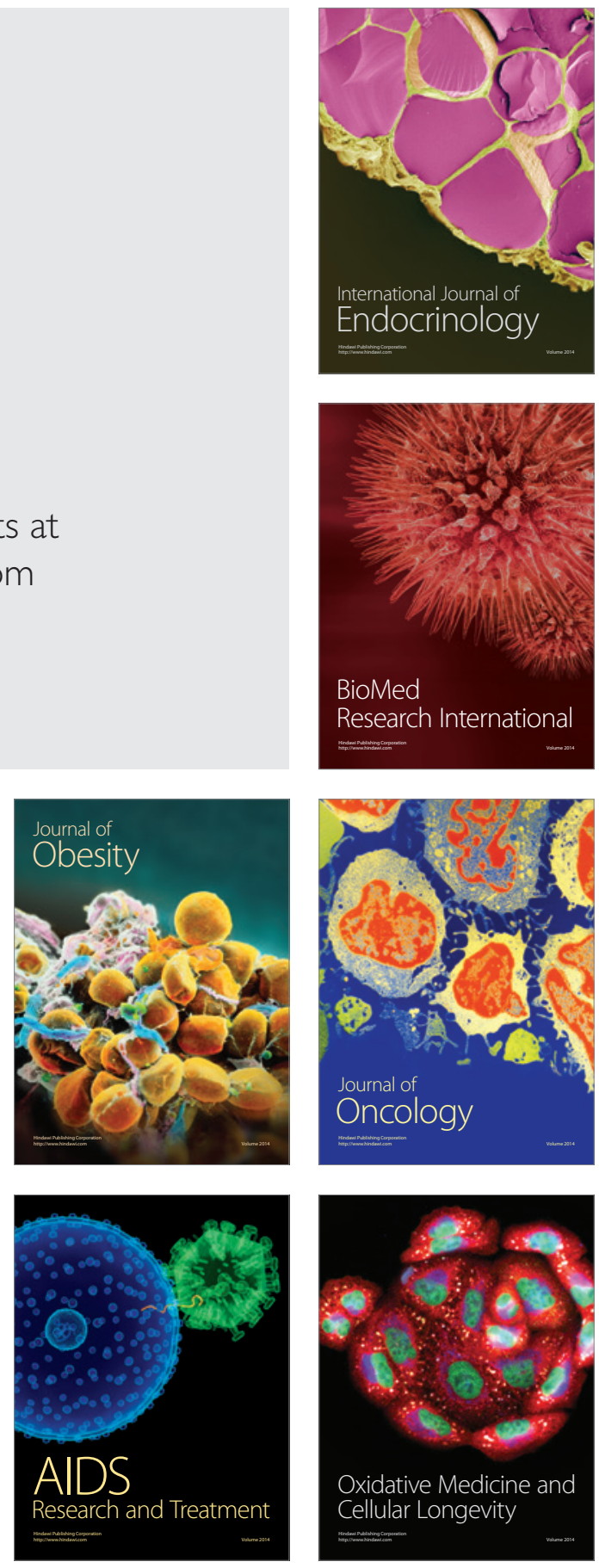